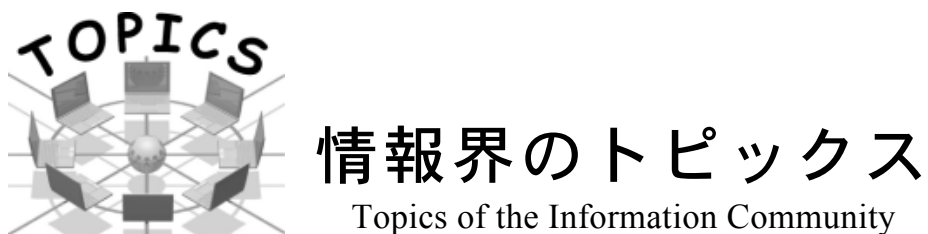

\section{米国議会がOrphan Works法案を提出}

数か月にわたる折衝の後, 米国議会は, 著作権 者が不明である著作物に対処する法案Orphan Works Billを提出した。Orphan Works（孤児作品）とは， まだ著作権保護下にあるものの, その所有者が突 き止められない著作物である。下院の知的財産小 委員会 (House Subcommittee on Courts, the Internet and Intellectual Property）で審議されることになる。

この法案では, Orphan Worksの再利用をしやす くする目的から，十分に誠実な探索の努力を尽く しても著作権保有者を特定できなかった場合に対 して, 後から著作権違反として訴えられたとして も, そこで適用される罰則を最小限にすることが 盛り込まれている。

研究図書館協会 (ARL) の事務局長であるPrue Adlerは, 法案は不完全であるとしても一歩前進で あり，ARLはこの法案が通るよう力を尽くすと述 べている。

(http://www.asmp.org/pdfs/HR_Orphan_Works_ Act_of_2_1.pdf)(http://thomas.loc.gov/cgi-bin/bdquery/ z?d109: h.r.05439:)(accessed 2006-06-06)

\section{エルゼビア社がハイブリッドOAジャーナルを提供}

エルゼビア社は, 物理学のジャーナル 6 誌を 5 月 から, そのほか異なる分野のジャーナル 30 誌以上 をその後 2 㖇で, ハイブリッドのオープンアク セスジャーナルとすることを発表した。主任編集 者のCarl Schwarzがメーリングリストに送ったメッ セージによれば,この計画によって, エルゼビア 社は, スポンサーシップ費支払いのオプション （sponsored option）を論文の著者に提供すること になる。対象誌への論文掲載が既に決まっている 執筆者がこのオプションを選ぶと, その論文は ScienceDirect経由で, 非購読者も自由にアクセスで きるようになる。

世界中で約1千万の研究者は既に, 所属する機関 を通して,これらのジャーナルにアクセスできる
が, 少数の研究者から非購読者も自由に読めるよ うなオプションを要請されていたことから生まれ たアイデアである。このオプションを提供する最 初の6誌は, Nuclear Physics A, Nuclear Physics B Proceedings Supplements, Physics Letters B, Nuclear Instruments and Methods A, Astroparticle Physicsである。

スポンサーシップ費は，1論文 3,000 ドルで，税金 やカラー印刷費といった著者負担費用はそれとは 別料金となる。なお，論文掲載に対する金銭的誘 引となるのを避けるために, 論文が採択されるま で,このオプションは著者に提供されない。

(http://www.earlham.edu/ peters/fos/fosblog.html) (http://www.elsevier.com/wps/find/authorshome. authors/physicslettersb) (accessed 2006-06-06)

\section{EC報告に対するALPSPの反応}

欧州委員会(European Commission)は，2年間にわ たる研究の結果として, 今年4月に報告書 “Study on the Economic and Technical Evolution of the Scientific Publication Markets in Europe” （ヨーロッ パにおける科学出版市場の経済的・技術的発展の 研究）を公表し, 公的資金を得た研究は発表後す ぐにパブリックアクセスを保証するよう勧告した。 この報告書に対し，学協会出版者協会 (Association of Learned and Professional Society Publishers, ALPSP）が反論を発表した。報告書の勧告に従い， 欧州委員会の資金を受けた研究の結果に対してセ ルフアーカイビングを義務付ければ, ジャーナル の購読数は減少するだろうし, 物理学の分野では 既に減少している, とALPSPは主張する。無料で アクセスできる論文が増えれば, 図書館がジャー ナルの購読をキャンセルするのではないか, と ALPSPは懸念している。

(http://ec.europa.eu/research/science-society/pdf/ scientific-publication-study_en.pdf)

(http://www.alpsp.org/news/ALPSPresponseECReport.pdf) (accessed 2006-06-06) 


\section{NIIが日本最大規模の電子ジャーナルアーカイブを 実現}

国立情報学研究所（NII）は国立大学図書館協会 と公私立大学図書館コンソーシアムとの共同で, 世界の主要な学術雑誌約 1,000 誌の 280 万論文の電 子ジャーナルアーカイブを導入し, 従来から構築 を進めてきた国内の電子ジャーナルアーカイブと 合わせて計 610 万件の学術論文を要する日本最大規 模の電子ジャーナルアーカイブを実現した。

この電子ジャーナルアーカイブは, 世界有数の 学術出版社Springer（シュプリンガー, ドイッ) と Oxford University Press（オクスフォード大学出版 局, イギリス）の 2 社が刊行する, 人文・社会科学 から理工学, 生命科学にわたる幅広い分野の学術 雑誌を創刊号(1847年)まで遡って, 1,900万ページ 分を電子化している。これらはNIIが提供する「電 子ジャーナル・リポジトリ（NII-REO）」に登載さ れ, 論文のタイトルや抄録は誰でもインターネッ トで検索することができる。また, 図書館コンソー シアムに加入している大学からは研究者や学生だ けでなく, 大学図書館の一般利用者も論文の本文 を見ることができる。

この電子ジャーナルアーカイブの導入は, 創刊 号から現在に至るまで切れ目ない知の継続性を確 保する先駆けとなり, また, 組織を超えたコンソー シアムでの取り組みにより, 電子ジャーナルを利 用する際のライセンス契約についても契約の安定 化と低コスト化という実績を上げることとなった。

今回の取り組みは, NIIが大学等との連携により 推進している最先端学術情報基盤（サイバー・サ イエンス・インフラストラクチャー：CSI）の重要 な柱として, 知の共有財産としての学術コンテン ツをNII と大学が共同で確保し, 安定的な提供と永 続的な保存を保証することを目的としたもので， 今後のさらなる最先端学術情報基盤の構築・整備 のひとつのステップとなるであろう。

(http://www.nii.ac.jp/news_jp/2006/06/610.shtml) (報道 発表取材2006-06-02)

\section{米国議会図書館のWebアーカイビング情報サイト}

米国議会図書館は, NDIIPP（The National Digital Information Infrastructure and Preservation Program : 全米デジタル情報の基盤と保存計画）と関連する プログラムとして, 2004年から進められているイ
ニシアティブ「Web Capture」の情報提供サイトを 公開した。イラク戦争, ヨハネ・パウロ 2 世の死去 に伴う教皇選出など, 同図書館が行っているWeb アーカイビング活動の主題と収集期間が一覧になっ ており, パイロットプロジェクトの成果を公開し た「MINERVA: Mapping the Internet Electronic Resources Virtual Archive」サイトや提携機関へのリ ンクによって, 収集したサイトのコンテンツを閲 覧することもできる。

そのほかに, Webアーカイビング技術開発の各 領域で使用したオープンソースソフトウェアの紹 介とハーベスティングに関するガイドラインや， 各コレクション作成の際に適用した資料収集基準, Webサイト運営者向けのQ\&A, International Internet Preservation Consortium (IIPC) ほか関連諸団体への リンクなどが掲載されている。

米国議会図書館広報部は, Web Capture開設の目 的が「歴史的に重要なWebサイトを保存する計画 に関する情報を提供し, それによって次世代の利 用者へのアクセスを可能にする」ことにあるとし ている。

(http://www.loc.gov/today/pr/2006/06-125.html) (http:// www.loc.gov/webcapture/) (accessed 2006-06-07)

\section{中国でWebコンテンツ著作権保護に向けた法整備}

中国で, 新たにWeb上にある著作物の権利侵害 を制限する法案が可決された。この法律によって, 文章, 公演, 録音・録画などのコンテンツを, ダ ウンロードやコピーできるようにWeb上にアップ する場合には, 本来の著作権者の許諾を得ること が義務付けられ, その際には著作権者へ使用料を 支払うことが定められた。同時に, 著作物のプロ テクトを解除できるツールやサービスを提供する ことや, デジタルコンテンツの著作権管理用デー タの削除・改変なども禁止される。

また, 著作権侵害サイトを発見した著作権者は 証拠書類を添えた書面によって, プロバイダに削 除依頼を申し立てることができる。著作権者から の申し立てを受けたプロバイダは, その旨をサイ 卜運営者に通知の上で, 違法サイトやサイトへの リンクを削除しなければならない。これらの条項 に違反した者には，10万元以下の濖金が科せられる。

同法は7月1日から施行される。 (http://english.gov.cn/2006-05/29/content_294701.htm) (http://www.chinalaw.gov.cn/jsp/contentpub/browser/ 
contentpro.jsp? contentid $=$ co2130926207) $(\mathrm{http}: / /$ news.xinhuanet.com/english/2006-05/29/content_ 4617592.htm) (accessed 2006-06-07)

\section{0年分以上の学術誌デジタルアーカイブが英国 の大学で利用可能に}

英国の合同情報システム委員会（JISC）とオク スフォード大学出版局 (OUP) との契約締結によ り, 1800 年代にまで遡るOUPの学術誌のデジタル アーカイブへの無料アクセスが, 英国の大学に提 供されることになった。

アクセス可能になるコレクション「Oxford Jouranal Archive」は, 人文科学, 医学, 自然科学, 法学, 社 会科学の各分野にわたる約140種の学術誌を, 創刊 号から1995年刊行分までPDF化して収録している。 掲載された論文は約 30 万件で，それぞれHTML形 式の見出しと抄録をはじめ, 各種の検索機能や CrossRef リンキングなどに対応するメタデータを 付与して提供される。各大学が選択できる契約才 プションは 2 種類あり, アーカイブへの無料アクセ スを保障するライセンスと, 各機関がアーカイブ のコンテンツを学内ネットワークにローカルに登 載できる有料ライセンスがある。

JISC は契約に先立ってトライアル期間を設け各 大学からフィードバックを募集していたが, それ に対して絶大な支持が寄せられていたことがJISC のコレクションチームマネージャーであるL. Estelle によって明かされている。JISCの見込みでは，も し英国で個々の大学がこのアーカイブを購入した 場合, 1 機関当たり8万ポンドの導入コストが計算 されていた。

(http://www.jisc.ac.uk/index.cfm?name=oup_journals) (http://www.jisc.ac.uk/coll_oxfordjournals.html) (accessed 2006-06-07)

\section{米国のNPOが低所得者支援インターネットチャン ネルを開設}

5年前から低所得者層向けの生活支援情報ポータ ル「Beehive」を運営していた米国の非営利組織One Economyが, 低所得者層にオンラインで情報を提 供する「Public Internet Channel（PiC）」の開設計画 を発表した。

PiCのコンテンツは, 防災や救急サービス, 育児 と教育支援, 健康, 求職や起業などの生計手段, 市民活動などで, 英語とスペイン語の2か国語で提 供されるが, 将来的には他の言語への対応も検討 されている。国や地方自治体の公共サービス情報 のポータルとして利用できるほか, 市民の意見を 交換する議論の場としての役割も担う。このプロ ジェクトの名誉委員長として名を連ねるObama上 院議員は, PiCのサービスが実現すれば，「地方で の暮らしや貧困による孤立のために, アクセスで きなかったり見つけられなかった情報」に簡単に アクセスできるようになるとしている。

One Economy は今後数か所の地域でプロトタイ プを運用することも計画しているが, メリーラン ド州ボルティモア市長からは，PiCを市民への情報 提供に使用する自治体の先駆けとなりたいとの意 が表明されている。

(http://www.thebeehive.org/) (http://www.oneeconomy.com/publicinternetchannel/)

(http://www.one-economy.com/publicinternetchannel/ PiC_Press_release_60806.doc) (accessed 2006-06-13) 